\title{
A SEGURANÇA JURÍDICA NA SIMULTANEIDADE DE AÇÕES DE CONTROLE CONCENTRADO DE CONSTITUCIONALIDADE
}

\author{
THE LEGAL SECURITY IN THE SIMULTANEITY OF \\ CONCENTRATED CONSTITUTIONAL CONTROL SHARES
}

\author{
José Laurindo de Souza Netto ${ }^{1}$ \\ Celso Hiroshi Iocohama ${ }^{2}$ \\ Ricardo Pinto Feistler ${ }^{3}$
}

RESUMO: O presente estudo tem por objetivo abordar a problemática da simultaneidade de ações de controle concentrado de constitucionalidade, perante o Supremo Tribunal Federal e os Tribunais de Justiça, sob o enfoque da segurança jurídica. Após breves considerações sobre o controle abstrato de constitucionalidade, investiga os efeitos vinculantes e transcendentes das decisões deliberadas pelo Pretório Excelso, à luz do ordenamento processual civil vigente. Para tanto, analisa a diferenciação entre os efeitos das medidas cautelares, a eficácia normativa e executiva da declaração de (in) constitucionalidade, abordando, ainda, a problemática da eficácia preclusiva da coisa julgada, frente à possibilidade da revisão da coisa julgada inconstitucional. Como solução para evitar a insegurança jurídica aos jurisdicionados e operadores do direito, em casos de simultaneidade de ações de controle de constitucionalidade, propõe o sobrestamento das ações na esfera estadual, até o julgamento definitivo pelo Supremo Tribunal Federal. Adota, como metodologia, a pesquisa doutrinária e do estudo de precedentes jurisprudenciais.

Palavras-chave: Constitucionalidade; Controle concentrado; Ações Simultâneas; Suspensão; Segurança jurídica.

\footnotetext{
${ }^{1}$ Pós-doutor pela Faculdade de Direito da Universidade Degli Studi di Roma - La Sapienza. Estágio de Pós-doutorado em Portugal. Professor no Mestrado da Universidade Paranaense - UNIPAR. Currículo Lattes: http://lattes.cnpq.br/8509259358093260. Orcid: https://orcid.org/0000-0002-69506128. E-mail: jln@tjpr.jus.br.

${ }^{2}$ Doutor em Direito pela Pontifícia Universidade Católica de São Paulo Educação, em Educação pela Universidade de São Paulo. Especialista em Docência pela Universidade Paranaense. Professor de Direito Processual Civil-UNIPAR Currículo Lattes: http://lattes.cnpq.br/1774869644885979. Orcid: https://orcid.org/0000-0002-0686-0330. E-mail: celso@ prof.unipar.br.

${ }^{3}$ Mestre em Direito Processual e Cidadania pela UNIPAR - Universidade Paranaense. Especialista em Metodologia do Ensino Superior. Especializando em Processo Penal. Possui graduação em Direito pela Universidade Positivo. Currículo Lattes: http://lattes.cnpq.br/2749918631440293. Orcid: https://orcid.org/0000-0001-6379-8484. E-mail: ricardofeistler@ hotmail.com.
} 
ABSTRACT: The purpose of this study is to address the issue of simultaneous actions to control the constitutionality, before the Federal Supreme Court and the Courts of Justice, under the focus of legal certainty. After brief considerations on the abstract control of constitutionality, it investigates the binding and transcendent effects of decisions deliberated by the Praetorium Excelso, in light of the current civil procedural law. In order to do so, it analyzes the difference between the effects of the precautionary measures, the normative and executive effectiveness of the declaration of (in) constitutionality, also addressing the problematic of the preclusive effectiveness of the res judicata, against the possibility of reviewing the thing judged unconstitutional. As a solution to avoid legal uncertainty to the courts and legal operators, in cases of simultaneous actions of constitutionality control, proposes the overrun of actions at the state level, until the final judgment by the Federal Supreme Court. It adopts, as methodology, the doctrinal research and the study of jurisprudential precedents.

Keywords: Constitutionality; Concentrated control; Simultaneous Actions; Suspension; Legal certainty.

Sumário: 1. Introdução; 2. O princípio da simetria constitucional; 3. O controle simultâneo de constitucionalidade e a suspensão da ação de controle concentrado na esfera estadual; 4. Stare Decisis, o efeito vinculante e transcendente da ratio decidendi nas ações de controle de constitucionalidade; 5. A eficácia e a natureza dos provimentos liminares, a eficácia normativa e executiva da declaração de (in) constitucionalidade; 6 . A controvérsia acerca da eficácia preclusiva da coisa julgada, frente à possibilidade da revisão da coisa julgada inconstitucional; 7. Considerações finais; 8. Referências.

\section{INTRODUÇÃO}

O presente estudo tem por objetivo refletir sobre a melhor técnica processual para salvaguardar a segurança jurídica em sede de simultaneidade de ações de controle concentrado de constitucionalidade - especificamente as ações diretas de inconstitucionalidade e ações declaratórias de constitucionalidade-, perante o Supremo Tribunal Federal e os Tribunais de Justiça.

Com o advento do atual Código de Processo Civil, introduzido pela Lei ${ }^{\circ}$ 13.105, de 16.3.2015, a partir da exegese do art. 926 do CPC, constata-se o dever dos Tribunais pátrios não só de uniformizar suas jurisprudências, mas também de mantêlas estáveis, íntegras e coerentes, denotando a intenção do legislador em reforçar os instrumentos jurídicos que possam garantir a maior segurança jurídica possível aos jurisdicionados. 
A expressão de origem latina stare decisis remete ao dever dos Tribunais em observar a sua própria jurisprudência, anuindo aos casos já decididos em hipóteses semelhantes, podendo ser entendida como um dever de vinculação horizontal dos órgãos julgadores aos precedentes dos Tribunais aos quais se encontram subordinados.

O artigo 927 do CPC, a seu turno, ao elencar as decisões a serem observadas pelos juízes e tribunais, alargou as hipóteses vinculativas, que passaram a abranger o dever de serem aplicadas as decisões do Supremo Tribunal Federal, em sede de controle concentrado de constitucionalidade, denotando também um dever de vinculação vertical dos Tribunais pátrios ao stare decisis definidos pelo intérprete máximo da Constituição Federal.

Em sede de controle concentrado de constitucionalidade, especialmente nas ações diretas de inconstitucionalidade e declaratórias de constitucionalidade - e desde que se trate de lei ou ato normativo que regulamente normas de reprodução obrigatória pelos Estados Membros em suas Constituições Estaduais-, é possível que a legislação de um determinado Estado da federação tenha a sua constitucionalidade questionada perante o respectivo Tribunal de Justiça e que lei de idêntico teor, do mesmo ou ainda de outro Estado da Federação, seja simultaneamente impugnada perante o Supremo Tribunal Federal, mudando-se apenas o parâmetro de constitucionalidade, ou seja, a Constituição Federal e a Constituição Estadual.

Nessa seara, surgem diversos debates, tais como: se essas ações forem distribuídas simultaneamente, como aferir a competência para o julgamento? Haverá a necessidade de suspender o curso de uma das demandas? E se a ação simultânea, na esfera estadual, for de outro estado da federação? Se as decisões forem distintas, qual delas deverá prevalecer? É possível discutir a matéria perante o Supremo Tribunal Federal, caso a ação na esfera estadual já tenha transitado em julgado perante o Tribunal de Justiça? 
Dentro desse contexto, exsurge a problemática para o operador jurídico, na esfera estadual, pois ao mesmo tempo em que deve dar uma solução jurisdicional à controvérsia instaurada perante seu âmbito de atuação, há também a necessidade de alinhar-se ao entendimento do Pretório Excelso, com manifesto caráter vinculante.

É nessa perspectiva que o presente estudo, sem a pretensão de esgotar o tema, se propõe a responder aos questionamentos formulados, além de abordar alguns aspectos relevantes nessa problemática: os efeitos vinculantes e transcendentes da coisa julgada material das decisões do Supremo Tribunal Federal e a eficácia preclusiva da coisa julgada frente à possibilidade da revisão da coisa julgada inconstitucional.

Após uma breve introdução sobre o controle de constitucionalidade e investigar questões atinentes aos tópicos apontados, propõe como solução jurídica a suspensão da ação de controle concentrado de constitucionalidade na esfera estadual, até o julgamento definitivo da ação simultânea proposta perante o Pretório Excelso, ainda que se trate de lei ou ato normativo de outro estado da federação.

Como método de abordagem, utiliza-se as técnicas de pesquisa doutrinária e estudo de precedentes jurisprudências da Corte Suprema.

O artigo está estruturado em tópicos que analisarão, brevemente, conceitos inerentes ao controle concentrado de constitucionalidade, abrangendo o princípio da simetria constitucional, a competência originária para o julgamento de ações simultâneas de controle de constitucionalidade, a definição de stare decisis, o efeito vinculante e transcendente da ratio decidendi, o efeito da medida cautelar em sede de controle de constitucionalidade, a distinção entre eficácia normativa e eficácia executiva da declaração de (in) constitucionalidade, a possibilidade da revisão da coisa julgada inconstitucional, com seus respectivos desdobramentos na garantia da segurança jurídica das decisões judiciais, finalizando-se com a conclusão proposta. 


\section{O PRINCÍPIO DA SIMETRIA CONSTITUCIONAL}

No ordenamento legal pátrio, o controle de constitucionalidade é misto, pois pode ser exercido tanto de forma concentrada, pelo órgão jurisdicional que detém a competência exclusiva para a sua análise, como de forma difusa, onde a inconstitucionalidade é reconhecida incidentalmente em demanda que não foi ajuizada para esse fim específico.

Nas palavras de Luiz Roberto Barroso, o controle concentrado de constitucionalidade "é um exercício atípico de jurisdição, por que nele não há um litígio ou situação concreta a ser solucionado mediante a aplicação da lei pelo órgão julgador. Seu objetivo é um pronunciamento acerca da própria lei” (2010, p. 180). Denota-se que seu escopo não é precipuamente a resolução de um caso concreto, mas sim examinar a constitucionalidade da lei ou do ato normativo federal ou estadual em abstrato.

O Supremo Tribunal Federal, nos termos do art. 102, "a”, da Constituição Federal, detém a competência exclusiva para julgar, originariamente, a ação direta de inconstitucionalidade de lei ou ato normativo federal ou estadual e a ação declaratória de constitucionalidade de lei ou ato normativo federal, quando o parâmetro de controle for a Constituição Federal. A primeira tem o intuito de declarar a inconstitucionalidade de uma lei, total ou parcialmente, enquanto a segunda objetiva a confirmação da constitucionalidade de determinada lei, de forma a garantir que essa constitucionalidade não seja mais questionada em outras ações.

No âmbito estadual, quando o parâmetro de constitucionalidade é a Constituição Estadual, a competência é exercida pelos Tribunais de Justiça, frente a leis ou atos normativos municipais ou estaduais, conforme a exegese do art. $125, \S$ $2^{\circ}$, da Constituição Federal.

Desse contexto, o primeiro questionamento que surge na temática de processos simultâneos de controle concentrado de constitucionalidade, diz respeito à 
competência dos Tribunais de Justiça para apreciarem a (in) constitucionalidade de normas estaduais, ao argumento de que, ainda que se invoque como parâmetro de constitucionalidade a Constituição Estadual, a norma decorre de mera reprodução da Constituição Federal.

A partir da competência concorrente prevista no art. $24, \S 1^{\circ}$, da Carga Magna, que limita a competência da União a estabelecer normas gerais, reservando aos Estados membros da Federação a competência legislativa suplementar, conforme exaustivamente debatido na ADI 2344/QO, Rel. Min. Celso de Mello, exsurge o denominado condomínio legislativo.

O princípio da simetria pode ser definido como um princípio de interpretação da nova hermenêutica constitucional, destinado a identificar normas de extensão na Constituição Federal, que devem ser necessariamente produzidas pelas Constituições estaduais e é destinado a identificar as normas da Constituição Federal que, mesmo não gerando a obrigação de reprodução, são facultativamente replicadas na esfera estadual, dentro das suas particularidades. A sua função essencial é o de servir como um limitador, para que os Estados não colidam com o norte constitucional da carta da república.

O Pretório Excelso, ao julgar a Reclamação nº 383/SP, Rel. Ministro Moreira Alves e o Agravo Regimental na Reclamação no 425, Rel. Ministro Néri da Silveira, assentou que não configura usurpação de competência do Pretório Excelso, quando os Tribunais de Justiça analisam, em controle concentrado, a constitucionalidade de leis municipais e estaduais, frente a normas insertas nas respectivas constituições estaduais, que reproduzem regra da Constituição Federal de observância obrigatória.

A partir desses julgamentos, restou assentado que os parâmetros de controle federal e estadual guardam autonomia entre si, para fins de definir se o Tribunal competente para se pronunciar acerca da inconstitucionalidade de uma lei ou ato normativo local, com possibilidade de recurso extraordinário se a interpretação da 
norma constitucional estadual, que reproduz a norma constitucional federal de reprodução obrigatória pelos Estados, contraria o sentido e o alcance desta.

A temática foi recentemente enfrentada pelo Supremo Tribunal Federal em sede de repercussão geral, no RE 650898/RS, Rel. p/ acórdão Min. Roberto Barroso, j. em 01.02.2017, oportunidade em que respondeu afirmativamente à seguinte indagação: nos casos em que as Cartas estaduais reproduzem preceitos da Constituição Federal, por meio das técnicas de transposição ou remissão, pode o Tribunal de Justiça, ao definir o conteúdo da norma presente na Carta estadual, examinar preceitos do Diploma Maior?.

Nesse julgamento, foi fixada a tese no sentido de que os Tribunais de Justiça podem exercer controle abstrato de constitucionalidade de leis municipais utilizando como parâmetro normas da Constituição Federal, desde que se trate de normas de reprodução obrigatória pelos Estados.

Importa destacar que, ainda que a tese reafirmada tenha feito referência apenas a normas municipais, a ratio decidendi se aplica também às leis e atos normativos estaduais, sempre que o parâmetro de confronto seja norma de reprodução obrigatória, ainda que por remissão, inserta na Constituição Estadual.

Portanto, em caso de simultaneidade de ações de controle de constitucionalidade concentrado, na esfera federal e estadual, os Tribunais Estaduais detêm legítima competência para o conhecimento e julgamento da demanda, sempre que suscitado como parâmetro de constitucionalidade as normas de reprodução obrigatória insertas nas Constituições Estaduais ou na lei orgânica no Distrito Federal.

\section{O CONTROLE SIMULTÂNEO DE CONSTITUCIONALIDADE E A SUSPENSÃO DA AÇÃO DE CONTROLE CONCENTRADO NA ESFERA ESTADUAL}

Superada a controvérsia sobre a competência para o conhecimento das ações simultâneas de controle de (in) constitucionalidade, exsurge outra problemática para 
o operador do direito, na esfera estadual: diante do caráter vinculante da decisão da Corte Suprema, haverá a necessidade de suspensão da ação de controle concentrado de constitucionalidade na esfera estadual?

Dado o caráter vinculante das decisões proferidas pela Corte Suprema, a deliberação, em sede de controle abstrato de constitucionalidade, vinculará o Tribunal Estadual, nos termos expressos no art. 927, I, do CPC; porém, de forma contrária, eventual decisão da Corte Estadual não vinculará o Pretório Excelso.

Quando se trata de idêntica lei estadual, questionada simultaneamente perante o Supremo Tribunal Federal e o Tribunal de Justiça, a necessidade do sobrestamento da ação na esfera estadual foi deliberada no julgamento da Reclamação 425/RJ, Rel. Min. Néri da Silveira, a partir do voto-vista do Min. Moreira Alves. Esclareceu-se que, diferentemente da Reclamação 383, na qual se analisara a competência dos Tribunais de Justiça para o julgamento de ações de controle concentrado de constitucionalidade frente a leis municipais, a questão versava sobre a tramitação simultânea de ações diretas de inconstitucionalidade, com relação à mesma lei estadual.

Nessa oportunidade, ponderou-se que, se não houver tramitação paralela de ações, a interpretação conferida pelo Tribunal de Justiça dará margem a recurso extraordinário, havendo, portanto, um controle a posteriori, oportunizando ao Supremo Tribunal Federal aferir se a interpretação a que chegou a Corte Estadual condiz com a exegese conferida à interpretação do preceito constitucional reproduzido.

Entretanto, em havendo tramitação paralela, sobre lei idêntica, deve a ação de controle concentrado ser suspensa na esfera estadual, pois o exame a ser aferido pelo Pretório Excelso vinculará a decisão na esfera estadual, motivo pelo qual, se julgada a inconstitucionalidade da norma, a eficácia erga omnes dessa declaração tornará sem objeto a ação estadual. Acaso julgada constitucional a norma pela Suprema Corte, haverá igualmente vinculação do Tribunal Estadual, quanto à 
interpretação da norma de reprodução obrigatória, podendo o Tribunal de Justiça prosseguir no exame de constitucionalidade frente aos preceitos constitucionais estaduais, que não sejam de reprodução obrigatória.

Esse entendimento foi reafirmado no julgamento do Ag. Reg.na Petição 2.701-9/SP, Rel. Min. Maurício Corrêa, Rel. p/ Acórdão Min. Gilmar Mendes, oportunidade em que se ponderou que, a partir da eficácia erga omnes do pronunciamento sobre a constitucionalidade de uma norma, frente ao parâmetro constitucional federal utilizado, não pode o Tribunal Estadual decidir de forma diversa, pois outorgar eficácia transcendente à decisão equivaleria a atribuir força de interpretação autêntica à decisão do Pretório Excelso.

Constou do voto proferido: "pode-se reconhecer essa consequência se se admitir que as decisões do STF são dotadas de efeito vinculante, que não se limite à parte dispositiva, mas se estende aos fundamentos determinantes da decisão".

Insta esclarecer, contudo, que o entendimento exarado pelo Ministro Gilmar Mendes não é pacifico no Supremo Tribunal Federal. Ainda há muitos debates no que toca à eficácia transcendente dos motivos determinantes, principalmente após a entrada em vigor no novo CPC, o qual, segundo Andressa Junior e Barbosa (2017, p. 872) "reconhece explicitamente que a tese afirmada pela decisão proferida em controle concentrado de constitucionalidade produz efeitos vinculantes e que seu desrespeito possibilita a propositura de reclamação".

Necessário dizer, portanto, que na seara de processos simultâneos, inexiste controvérsia no Pretório Excelso, sobre a obrigatoriedade da suspensão da ação estadual e o cabimento de reclamação, quando se verificar a identidade entre o objeto combatido (ato normativo cuja constitucionalidade se questiona no âmbito estadual e federal simultaneamente) e o parâmetro de confronto (norma de reprodução obrigatória). 


\section{STARE DECISIS, O EFEITO VINCULANTE E TRANSCENDENTE DA RATIO DECIDENDI NAS AÇÕES DE CONTROLE DE CONSTITUCIONALIDADE}

O presente estudo propõe que, a partir do atual CPC, a suspensão da ação de controle concentrado, na esfera estadual, também deve ocorrer quando se constate a ocorrência de processo simultâneo perante o Pretório Excelso, que impugne lei de natureza idêntica, ainda que se trate de legislação de outro estado da federação, como medida que melhor salvaguarda a força vinculante dos precedentes e a segurança jurídica.

O conceito de stare decisis é fundamental para compreender-se a lógica vinculativa nos ordenamos jurídicos pautados na sistemática da commom law, não apenas no plano horizontal, mas também vertical, uma vez que os precedentes judiciais decididos e declarados por um Tribunal Superior possuem eficácia vinculante em face de todos os órgãos e juízes hierarquicamente inferiores, não estando apenas vinculados à própria Corte (BONAVIDES, 2003).

A expressão stare decisis, extraída da locução latina stare decisis et non quieta movere, que pode ser traduzida como a conduta de ser mantido o que já foi decidido, sem alteração do que restou estabelecido, indica o ideal jurídico de conferir segurança jurídica aos jurisdicionados, de forma a conferir uma coesão na interpretação legislativa pelos tribunais pátrios, por meio da vinculação à ratio decidendi.

Por diversas oportunidades, o efeito vinculante das decisões deliberadas em sede de controle abstrato de constitucionalidade foi ampliado, com fundamento na doutrina da transcendência dos motivos determinantes. Em outras palavras: juízes e tribunais devem acatamento não apenas à conclusão do acórdão, mas igualmente às razões de decidir. (BARROSO, 2012). 
Nesse viés, a fundamentação ganha notável sentido extraprocessual, servindo como norte informador, com vistas a garantir a segurança jurídica e previsibilidade aos jurisdicionados, tendo efeitos para além das partes litigantes, de forma que a ratio decidendi ultrapassa os limites subjetivos da demanda, protegendo os jurisdicionados de forma global, proporcionando maior segurança jurídica, devendo ser aplicada aos casos posteriores, em casos semelhantes. (Marinoni, 2018).

Os fundamentos que formam a ratio decidendi importam pelo fato de não se aplicarem exclusivamente às partes litigantes do caso concreto, interessando também aos demais magistrados, que têm a missão de dar coerência à aplicação do direito e, consequentemente, aos jurisdicionados, que buscam conhecer a dimensão e o significado dos precedentes, a fim de ter obterem uma previsibilidade da interpretação do ordenamento legal pátrio.

Nessa perspectiva, a ratio decidendi não se limita apenas à parte dispositiva, abarcando os elementos que compõem a decisão, ou seja, fundamentação, dispositivo e relatório, que possibilitam extrair uma tese jurídica ou a interpretação da norma consagrada na decisão, a ser aplicada nos demais casos futuros, em situações semelhantes, de forma vinculante, enquanto os argumentos periféricos, denominados de obter dictum, não a integram.

Na Reclamação 17954 AgR/PR, sob a égide do CPC/73, a jurisprudência do STF se firmou no sentido de que a eficácia vinculante dos acórdãos abrange apenas o objeto examinado pela Corte, de modo que a vinculação pelos demais órgãos se dá apenas frente ao dispositivo e não à fundamentação dos julgados, obstando o reconhecimento de reclamações que não guardem correlação com o mesmo diploma legal que deu ensejo ao precedente vinculante.

Entretanto, a partir da vigência do $\mathrm{CPC} / 15$, o atual sistema processual civil passou a prever expressamente a existência de precedentes de observância obrigatória, como nos casos das súmulas vinculantes e as decisões definitivas do 
Supremo Tribunal Federal, em controle concentrado de constitucionalidade, conforme se depreende dos arts. 926, 927 e 928 do CPC (Barroso, 2012).

Justifica-se, assim, uma nova interpretação dogmática e jurisprudencial, para o fim de reconhecer-se os efeitos transcendentes dos motivos determinantes da interpretação conferida pela Suprema Corte, a legislações estaduais de idêntico teor, ainda que se trate de norma estadual de outro estado da federação.

Assim, uma vez constada a similitude da legislação impugnada, atinentes à mesma norma de reprodução obrigatória pelos estados, considerando a eficácia transcendente da ratio decidendi deliberada em sede de controle concentrado de constitucionalidade às demais hipóteses semelhantes debatidas nas esferas estaduais, também por esse viés se justifica o sobrestamento da ação na esfera estadual até a deliberação da Suprema Corte.

Tal se dá pelo fato de que a ratio decidendi da decisão que declarar a (in) constitucionalidade da lei de um Estado membro da federação deverá servir de norte, pela transcendência dos motivos determinantes, evitando-se, assim, decisões conflitantes.

\section{A EFiCÁCia e a NATUREZA dOS PROVimentos LiminARES, A EFICÁCIA NORMATIVA E EXECUTIVA DA DECLARAÇÃO DE (IN) CONSTITUCIONALIDADE}

Para uma melhor compreensão dos motivos justificadores da tese proposta, ganha relevo a compreensão dos conceitos da eficácia e da natureza antecipatória dos provimentos liminares, do julgamento de mérito e da eficácia executiva da declaração de (in) constitucionalidade.

Não se pode perder de vista que, em sede de controle concentrado de constitucionalidade, está-se no âmbito de processo de jurisdição abstrata e objetiva, 
permitindo o sistema pátrio, igualmente, o controle difuso, com declaração incidental de (in) constitucionalidade.

É possível, no controle concentrado de constitucionalidade, que a lei ou ato normativo impugnado tenham a sua eficácia suspensa, com efeitos ex nunc, até a prolação de mérito definitiva, podendo, ainda, ser concedido efeito retroativo, hipótese em que tornará aplicável a legislação anterior acaso existente, salvo expressa manifestação em sentido contrário (art. 11, $\S 1^{\circ}$ e $2^{\circ}$, da Lei 9.868/98).

Para as ações declaratórias de constitucionalidade, a lei de regência prevê, como efeito do deferimento da medida cautelar, pela maioria absoluta do plenário, a determinação para que os juízes e os Tribunais suspendam o julgamento dos processos que envolvam a aplicação da lei ou do ato normativo objeto da ação, até seu julgamento definitivo, ou seja, a suspensão das ações em sede de controle difuso de constitucionalidade da norma (art. 21 da Lei 9.868/98).

A sentença que declara a constitucionalidade ou a inconstitucionalidade da norma tem eficácia ex tunc, o que significa dizer que o vício declarado acarreta a nulidade da norma desde a sua origem.

O efeito vinculante de tais decisões é uma decorrência natural do controle do sistema de controle de constitucionalidade, pois constituiria verdadeiro paradoxo reconhecer-se a eficácia erga omnes da sentença e, ao mesmo tempo, desobrigar os demais órgãos jurisdicionais e autoridades administrativas de seu cumprimento, pois tal caracterizaria uma decisão sem autoridade prática.

Entretanto, quanto ao efeito vinculante, ainda que o julgamento de mérito tenha efeitos ex tunc, seu termo inicial é deflagrado com a sentença que declara a inconstitucionalidade da norma, que se dá com a data da publicação do acórdão pelo Pretório Excelso, conforme se depreende do art. 28 e parágrafo único da Lei 9.868/99.

A partir do termo inicial do efeito vinculante, exsurge o fato de que a procedência da declaração de inconstitucionalidade em controle concentrado não acarreta a imediata desconstituição das relações jurídicas subjetivas anteriores a elas 
contrárias, afirmadas por sentença judicial, especialmente quando não houver a suspensão da norma em caráter liminar. Não basta, assim, a declaração de inconstitucionalidade em sede de controle concentrado para desconstituí-las, tendo em vista que o efeito vinculante em tais circunstâncias é superveniente e é realizado de forma abstrata. Quer dizer, as ações de controle concentrado de constitucionalidade não podem ultrapassar a sua própria finalidade, que se restringe à análise de constitucionalidade, culminando com a exclusão do ordenamento legal dos atos incompatíveis com o texto constitucional.

Assim, em relação às relações jurídicas individuais, constituídas em data anterior ao julgamento de mérito da declaração de inconstitucionalidade, em sede de controle abstrato pela Corte Suprema, em casos de simultaneidade de ações, acaso se julgue pela constitucionalidade na norma, na esfera estadual, é possível que nesse ínterim surjam várias situações concretas julgadas e acobertadas pela coisa julgada material, com fundamento em lei ou ato normativo posteriormente julgado inconstitucional ou, ainda, julgamento pela inconstitucionalidade de lei na esfera estadual e que, posteriormente, lei de idêntico teor, de outro estado da federação, seja posteriormente declarada constitucional.

Essas situações dão margem à discussão sobre a possibilidade de que o entendimento superveniente da declaração de (in) constitucionalidade pelo Supremo Tribunal Federal seja aplicado a casos concretos subjetivos já julgados e estabilizados.

O Supremo Tribunal Federal, no julgamento do RE 730462/SP, de Relatoria do Min. Teori Zavascki Filho, discutiu sobre a possibilidade da aplicação superveniente da declaração de inconstitucionalidade aos casos já julgados.

Naquela ocasião, tendo em vista que já havia transcorrido mais de dois anos da declaração de constitucionalidade incidenter tantum, a qual foi posteriormente tida por inconstitucional pelo Pretório Excelso, foi firmada a tese 733, com repercussão geral, sob a égide do CPC/73, segundo a qual a decisão do STF declarando a 
constitucionalidade ou inconstitucionalidade de preceito normativo não produz a automática reforma ou rescisão das sentenças anteriores que tenham adotado entendimento diferente; para que tal ocorra, será indispensável a interposição do recurso próprio ou, se for o caso, a propositura da ação rescisória própria, nos termos do art. 485,V, do CPC, observado o respectivo prazo decadencial (CPC, art. 495). Ressalva-se desse entendimento, quanto à indispensabilidade da ação rescisória, a questão relacionada à execução de efeitos futuros da sentença proferida em caso concreto sobre relações jurídicas de trato continuado.

Ponderou-se, nesse precedente, que a superveniência de julgamento plenário pelo Supremo Tribunal Federal, em sede de controle abstrato de constitucionalidade, seja declarando a inconstitucionalidade ou a constitucionalidade de determinado diploma normativo, não tem o condão, por si só, de invalidar anterior sentença em sentido contrário, sendo de rigor a sua impugnação mediante recurso próprio ou, ainda, a sua desconstituição, em caso de trânsito em julgado, dentro do prazo decadencial para o ajuizamento de ação rescisória, tendo em vista que a coisa julgada é uma garantia essencial do direito fundamental à segurança jurídica.

Dessume-se, portanto, que o efeito vinculante das decisões da Corte Suprema, quando do julgamento de mérito das ações declaratórias de inconstitucionalidade, não decorre da declaração de inconstitucionalidade da norma, por si só, mas sim da sentença que a declara, de onde exsurge que o efeito vinculante tem efeitos para o futuro, não atingindo atos pretéritos.

Assim, acaso não se suspenda a ação na esfera estadual, é possível que o Tribunal local conclua pela constitucionalidade da norma estadual e que, posteriormente, o Supremo Tribunal Federal, julgando lei de idêntico teor de outro estado da federação e interpretando a mesma norma estadual de reprodução obrigatória, a tenha por inconstitucional, gerando, dessa forma, efeitos práticos contraditórios, em relação a diplomas legais de idêntico teor, malferindo a necessária segurança jurídica que se espera das decisões emanadas pelo Poder Judiciário. 


\section{A CONTROVÉrSiA ACERCA DA EFICÁCIA PRECLUSIVA DA COISA JULGADA, FRENTE À POSSIBILIDADE DA REVISÃO DA COISA JULGADA INCONSTITUCIONAL}

$\mathrm{Na}$ esfera dos processos subjetivos, o atual CPC, nos arts. $525, \S 1^{\circ}$, III e $\S$ 12 a 14 e $535, \S 5^{\circ}$ e $7^{\circ}$, prevê a possibilidade de arguição, em sede de impugnação ao cumprimento de sentença, da inexigibilidade do título ou da obrigação, quando o título executivo judicial estiver fundado em lei ou ao normativo considerado inconstitucional pelo Supremo Tribunal Federal, ou fundado em aplicação ou interpretação da lei ou do ato normativo tido pelo Supremo Tribunal Federal como incompatível com a Constituição Federal, em controle de constitucionalidade concentrado ou difuso.

O $\S 14$ do art. 525 do CPC/15 faz a ressalva de que a arguição de inconstitucionalidade superveniente ao trânsito em julgado do título executivo judicial poderá ser suscitada em sede de impugnação ao cumprimento de sentença, desde que a decisão do Supremo Tribunal Federal seja anterior ao trânsito em julgado da decisão exequenda.

No julgamento da ADI 2418/DF, a Suprema Corte analisou a constitucionalidade dos arts. 741 e 475-L do CPC/73, reproduzidos nos arts. 525, §§ 12 e 14 e $535, \S 5^{\circ}$ do $\mathrm{CPC} / 15$, oportunidade em que foi enfrentada a controvérsia acerca da inconstitucionalidade dos referidos dispositivos legais, por ofensa ao princípio da coisa julgada.

Nesse julgamento, ao ponderar-se sobre a polêmica doutrinária entre os que consideram os dispositivos legais em questão inconstitucionais, por ofensa ao princípio da coisa julgada, e aqueles que defendem a prevalência máxima da supremacia da Constituição, considerando inexequível qualquer sentença 
inconstitucional, adotou-se interpretação in medio virtus, quer dizer, a virtude está no meio termo.

Reconheceu-se, outrossim, a constitucionalidade da impugnação da coisa julgada inconstitucional, desde que o pronunciamento do Supremo Tribunal Federal acerca da constitucionalidade ou inconstitucionalidade da norma tenha sido anterior ao trânsito em julgado.

Isso na medida em que a utilização do mecanismo de rescisão da coisa julgada material por via de impugnação ou de embargos à execução pressupõe a existência de precedente vinculante do Pretório Excelso, o que decorre da eficácia erga omnes das decisões que reconhecem a inconstitucionalidade da norma, seja em controle incidental ou concentrado, cujo escopo é harmonizar a garantia da coisa julgada com o primado da supremacia da Constituição.

Pontuou-se na ADI 2418/DF, Rel. Min. Teori Zavascki, a irrelevância da decisão da Corte Suprema acerca da constitucionalidade ou inconstitucionalidade de determinada norma ter sido deliberada em sede de controle concentrado ou difuso, eis que a distinção restritiva não é mais compatível com a evidente intenção do legislador em valorizar a autoridade dos precedentes emanados pelo guardião máximo da Constituição, que não pode ser hierarquizada simplesmente em função do procedimento em que a decisão foi tomada.

Sob esse enfoque, há idêntica força de autoridade nas decisões do STF tanto em ação direta quanto nas proferidas em via recursal, estas também com natural vocação expansiva, conforme reconheceu o STF no julgamento da Reclamação 4.335, Min. Gilmar Mendes, Dje 22.10.10, a evidenciar que está ganhando autoridade a recomendação da doutrina clássica de que a eficácia erga omnes das decisões que reconhecem a inconstitucionalidade, ainda que incidentalmente, deveria ser considerada 'efeito natural da sentença'. (...) É exatamente isso que ocorre, aliás, nas hipóteses previstas no parágrafo único do art. 949 do $\mathrm{CPC} / 15$, reproduzindo o parágrafo único do art. 481 do $\mathrm{CPC} / 73$, que submete aos demais Tribunais a eficácia vinculante das decisões do plenário do STF em controle de constitucionalidade, indiferentemente de terem sido tomadas em controle concentrado ou difuso" (ADI 2418/DF, p. 21/22). 
Conforme referido pelo Min. Luiz Fux no citado julgamento, na expressão adotada pelo Min. Celso de Melo, "é a dessubjetivação ou a objetivação das decisões do Supremo Tribunal Federal”.

Constata-se, portanto, que o fundamento da decisão de inconstitucionalidade, na impugnação em sede de cumprimento de sentença, deixou de ser a nulidade da lei inconstitucional e passou a ser a eficácia obrigatória da decisão de (in) constitucionalidade.

É com esse enfoque que, no sistema de controle de constitucionalidade pátrio, em que é possível o controle de constitucionalidade difuso, justifica-se a desconstituição da coisa julgada material, em processos subjetivos, quando houver anterior decisão do Pretório Excelso, conforme expressamente previsto nos arts. 525, $\S 12$ e 535, § $5^{\circ}$, do CPC, e diante da impossibilidade de que os tribunais ordinários neguem a aplicação da mesma solução constitucional adotada pela Corte Suprema, o que abarca a compreensão da ratio decidendi do precedente vinculante.

Assim, é possível a rescisão de sentenças transitadas em julgado revestidas de vício de inconstitucionalidade qualificado, quando a sentença estiver amparada em norma reconhecida como inconstitucional ou deixar de aplicar norma tida como constitucional pelo Pretório Excelso, desde que a aferição da norma pela Corte Suprema tenha sido anterior ao trânsito em julgado da sentença que lhe for contrária.

De outro vértice, quando a declaração de inconstitucionalidade pelo Pretório Excelso for posterior à formação da coisa julgada subjetiva, o termo inicial para a deflagração do prazo decadencial passou a ser o trânsito em julgado da decisão proferida pela Corte Suprema, conforme previsão do arts. 525, § 15 e 535, § $8^{\circ}$ do CPC.

A modificação legislativa, diferindo o termo inicial para a ação rescisória em casos de declaração de (in) constitucionalidade, não integrou a discussão debatida na ADI 2418/DF, pois nesse julgamento foram questionados apenas dispositivos do $\mathrm{CPC} / 73$. 
Tendo em vista que a inovação introduzida nos arts. 525 , § 15 e $535, \S 8^{\circ}$ do CPC/15 foi debatida apenas obter dictum, a controvérsia sobre a rescisão da coisa julgada material inconstitucional, via ação rescisória, quando a decisão do Pretório Excelso for proferida após o transcurso de dois anos do trânsito em julgado de sentença que lhe seja contrária, ainda pende de análise pela Suprema Corte.

Em crítica a essa inovação legislativa, aponta a abalizada doutrina que a admissão de rescisória, em face de decisão de inconstitucionalidade posterior à formação da coisa julgada "é voltar a confundir validade da lei com validade do juízo sobre a lei. É, fundamentalmente, esquecer da garantia constitucional da coisa julgada" (Marinoni, 2018). Isso na medida em que não se pode negar a autonomia da interpretação judicial sobre a lei.

Evidencia-se, assim, que a submissão da validade das decisões transitadas em julgado a uma condição atemporal, surgida após o trânsito em julgado do título executivo judicial, ou seja, com um prazo decadencial móvel, diferido no tempo, nas palavras do Min. Roberto Barroso, tem um impacto sobre a coisa julgada um pouco dramático.

Embora a constitucionalidade desses dispositivos legais ainda não tenha sido submetida à deliberação do Pretório Excelso, a partir dos precedentes já existentes, não se pode afastar a possibilidade de que venham a ser tido como inconstitucionais. No julgamento do RE 590.809/RS, Rel. Min. Marco Aurélio, com repercussão geral reconhecida, o Supremo Tribunal Federal, em decisão majoritária, reviu seu anterior entendimento sobre a Súmula 343 do STF - não cabe ação rescisória por ofensa a literal disposição de lei, quando a decisão rescindenda se tiver baseado em texto legal de interpretação controvertida nos tribunais-, passando a admitir a sua aplicação também quando se tratar de dissídio sobre questão constitucional (Marinoni, 2018).

A tese que restou fixada no julgamento do Tema 136, com repercussão geral, foi assentada nos seguintes termos: não cabe ação rescisória quando o julgado estiver em harmonia com o entendimento firmado pelo Plenário do Supremo à época da 
formalização do acórdão rescindendo, ainda que ocorra posterior superação do precedente.

Prevaleceu, assim, o entendimento da impossibilidade de admitir-se a rescisória como mecanismo de atualização de decisões proferidas em casos já julgados, ao último entendimento do Supremo Tribunal Federal sore determinada interpretação constitucional, diante da impossibilidade de transgredir-se os princípios da segurança jurídica, da confiança e da estabilidade das relações sociais, quando a decisão transitada em julgado foi respaldada por orientação jurisprudencial predominante à época do julgamento.

A conclusão sobre o descabimento de ação rescisória quando o julgamento tiver sido proferido em harmonia com o entendimento firmado pelo Plenário do Supremo Tribunal Federal, à época da formação do acórdão rescindendo, ainda que ocorra a posterior superação do precedente, é medida que se coaduna com os princípios da segurança jurídica e da estabilidade das relações sociais.

Entretanto, em se tratando de ação de controle concentrado de constitucionalidade, não se pode perder de vista que, contrariar a interpretação conferida pelo Pretório Excelso, é violar a interpretação da norma de reprodução obrigatória pelos estados, situação que diverge do controle incidental de constitucionalidade, posteriormente interpretado de forma diversa pelo Supremo Tribunal Federal.

Portanto, no contexto de simultaneidade de ações de controle concentrado, exsurge ainda mais a necessidade do sobrestamento da ação de controle concentrado na esfera estadual, eis que não se pode afastar a hipótese de que não venha a ser interposto recurso extraordinário, ou ainda a sua intempestividade, situação em que a interpretação estadual conferida não se sujeita à ação rescisória. 


\section{CONSIDERAÇÕES FINAIS}

A segurança jurídica é um dos postulados mais almejados na ordem jurídica, possibilitando aos jurisdicionados a condução de suas vidas de forma mais estável, de forma a ser um elemento precursor do Estado Democrático de Direito (Bonavides, 2003).

A eficácia vinculante das decisões do Pretório Excelso em controle de constitucionalidade, abrangendo a ratio decidendi, sejam elas tomadas em controle concentrado ou difuso, são de observância obrigatória pelos Tribunais Estaduais, motivo pelo qual não se justifica o afastamento da regra de suspensão da ação de controle de constitucionalidade abstrato, na hipótese de processos simultâneos, ainda que a análise pendente no Tribunal Superior diga respeito a legislação de outro estado da federação.

Nessa perspectiva, a aplicação do entendimento do intérprete máximo da Constituição Federal, pelos demais órgãos julgadores, nas instâncias ordinárias, traduz aos jurisdicionados um espírito de coesão e seriedade das decisões do Poder Judiciário, como um todo, postura a cada dia mais necessária para conferir a segurança jurídica tão desejada.

Não se pode falar em segurança jurídica ou no princípio da confiança, quando os Tribunais das instâncias ordinárias contrariam o entendimento da Corte Suprema, ao analisarem legislações de teor semelhante, ainda que de Estados distintos da federação. Tampouco se justifica que se entenda pelo sobrestamento, acaso o fosse determinado pelo Pretório Excelso em sede de repercussão geral, em sede de processo subjetivo, e afastar a necessária suspensão, em caso de simultaneidade de ações de controle concentrado de constitucionalidade, apenas por se tratar de legislação de um estado diverso da federação, ainda que se tratem de normas de idêntico teor, amparadas na mesma norma constitucional de reprodução obrigatória. 
Nas palavras de Sarlet (2005, p. 6), considerando que também a segurança jurídica coincide com uma das mais profundas aspirações do ser humano, viabilizando, mediante a garantia de uma certa estabilidade das relações jurídicas e da própria ordem jurídica como tal, tanto a elaboração de projetos de vida, bem como sua realização, desde logo é perceptível o quanto a ideia de segurança jurídica encontra-se umbilicalmente vinculada à própria noção de dignidade da pessoa humana.

A segurança jurídica é expressamente prestigiada no atual Código de Processo Civil, em sua Exposição de Motivos, ao proclamar que o princípio da segurança jurídica, ainda que de índole constitucional, se hospeda nas dobras do Estado Democrático de Direito e visa a proteger e a preservar as justas expectativas das pessoas, na medida em que todas as normas jurídicas devem tender a dar efetividade às garantias constitucionais, tornando segura a vida dos jurisdicionais, poupando-os de surpresas abruptas. E nesse aspecto, é fato que a segurança jurídica fica comprometida com a brusca e integral alteração do entendimento dos Tribunais sobre questões de direito.

Justifica-se, assim, que um dos pressupostos para que a segurança jurídica se efetive perpassa pela resolução de questões jurídicas idênticas de forma semelhante e não colidentes, independentemente do órgão julgador, garantindo uma previsibilidade ao jurisdicionado da resposta do Poder Judiciário a ser conferida em determinada situação.

O fato de se tratar de legislação de outro estado da federação é irrelevante, a partir da conceituação da ratio decidendi, eis que os motivos determinantes serão de observância obrigatória e não apenas a parte dispositiva, restando aos Tribunais Estaduais, em respeito à transcendência dos motivos determinantes, a observância e o acatamento da decisão exarada pela Corte Suprema.

Com efeito, ainda que uma declaração de constitucionalidade, na esfera estadual, não tenha o condão de modificar o ordenamento jurídico, terá efeito 
vinculante frente aos demais órgãos do Poder Judiciário e da administração pública e, acaso ocorra a situação hipotética de transitar em julgado o pronunciamento na esfera estadual, com superveniente entendimento contrário da Corte Suprema, não se poderá aplicar seus efeitos às relações jurídicas individuais transitadas em julgado, especialmente quando não se esteja frente a relações jurídicas de trato continuado.

Em tempos onde a transparência das decisões se comunica ampla e rapidamente pelos meios de comunicação social disponibilizados aos cidadãos, é notório que a imprevisibilidade das decisões judiciais contribui para enfraquecer o regime democrático de direito, eis que se traduz na mensagem de desigualdade e insegurança jurídica aos jurisdicionados.

Demonstra-se, portanto, que a segurança jurídica é a razão primordial a justificar a suspensão da ação de controle concentrado de constitucionalidade na esfera estadual, até a decisão definitiva do Supremo Tribunal Federal, em caso de simultaneidade de ações, sempre que estiver em foco a análise de lei ou ato normativo estadual de idêntico teor, ainda que originários de diferentes estados da federação, diante da inarredável vinculação à ratio decidendi das decisões exaradas pelo Supremo Tribunal Federal.

\section{REFERÊNCIAS}

ANDREASSA JUNIOR, Gilberto; BARBOSA, Claudia Maria. Teoria dos precedentes e sua incompatibilidade com o sistema deliberativo dos tribunais superiores. Revista Eletrônica do Curso de Direito da UFSM. Santa Maria, v. 12, n. 3, p. 861-888, dez. 2017. ISSN 1981-3694. Disponível em: http://dx.doi.org/10.5902/1981369426773. Acesso em: 30 mai. 2019.

BARROSO, L. R. Curso de direito constitucional contemporâneo; os fundamentos constitucionais e a Constituição do novo modelo. São Paulo: Saraiva. 2010.

BARROSO, L. R. O controle de constitucionalidade no direito brasileiro: exposição sistemática da doutrina e análise crítica da jurisprudência. 6.ed. rev. e atual. - São Paulo: Saraiva, 2012. 
BONAVIDES, P. Teoria Constitucional da democracia participativa. 2. ed. - São Paulo: Malheiros, 2003.

MARINONI, L. G.; ARENHART, S. C.; MITIDIERO, D. Código de Processo Civil Comentado - 4. Ed. rev. atual. e ampl.- São Paulo: Revista dos Tribunais, 2018.

MENDES, G.F.; MARTINS, Ives Gandra da Silva. Controle Concentrado de Constitucionalidade. 3. ed. - São Paulo: Editora Saraiva, 2009.

BRASIL. Supremo Tribunal Federal. Reclamação $\mathbf{n}^{\circ}$ 383/SP. Ação indireta de constitucionalidade, impugnação de Lei Municipal sob alegação de ofensa a dispositivos constitucionais estaduais que reproduzem dispositivos constitucionais federais. Disponível em: http://redir.stf.jus.br/paginadorpub/paginador.jsp?docTP=AC\&docID=86809. Acesso 10 mai.2019.

BRASIL. Supremo Tribunal Federal, AgRRcl $\mathbf{n}^{\mathbf{0}}$ 425/RJ. Representação de Inconstitucionalidade de Lei Estadual. Disponível em: http://redir.stf.jus.br/paginadorpub/paginador.jsp?docTP=AC\&docID=325930. Acesso em: 10 mai.2019

BRASIL. Supremo Tribunal Federal, Recurso Extraordinário no 730.462/SP. Declaração de inconstitucionalidade de preceito normativo pelo STF, eficácia normativa e eficácia executiva da decisão: Distinções. Disponível em: http://redir.stf.jus.br/paginadorpub/paginador.jsp?docTP=TP\&docID=9343495.

Acesso em: 14 mai.2019.

BRASIL. Supremo Tribunal Federal, Ação Direta de Inconstitucionalidade $\mathbf{n}^{\mathbf{o}}$ 2418/DF. Legitimidade das normas estabelecendo prazo de trinta dias para embargos à execução contra fazenda pública, (art. $1^{\circ}$-b da lei 9.494/97) e prazo prescricional de cinco anos para ações de indenização contra pessoas de direito público e prestadoras de serviços públicos (art. $1^{\circ}$-c da lei 9.494/97). Disponível em:http://redir.stf.jus.br/paginadorpub/paginador.jsp?docTP=TP\&docID=12036655 . Acesso em: 14 mai.2019.

BRASIL. Supremo Tribunal Federal. Recurso Extraordinário nº 650898/RS. Ação Direta de Inconstitucionalidade estadual. Parâmetro de controle. Regime de subsídio. verba de representação, $13^{\circ}$ salário e terço constitucional de férias. Disponível em http://redir.stf.jus.br/paginadorpub/paginador.jsp?docTP=TP\&docID=13413775. Acesso em: 21 mai. 2019. 
BRASIL. Supremo Tribunal Federal. Agravo Regimental em Petição no 2.701 AgR/SP. Aplicabilidade da Lei $n^{\circ}$ 8.437/92, dispõe sobre a concessão de medidas cautelares contra atos do Poder Público. Controle concentrado de inconstitucionalidade. ADI contrária a Lei estadual perante o STF. Disponível em: http://redir.stf.jus.br/paginadorpub/paginador.jsp?docTP=AC\&docID=369821. Acesso em: 21 mai. 2019.

ZAVASCKI, T.A. Eficácia das sentenças na jurisdição constitucional. $4^{\mathrm{a}} \mathrm{ed}$. rev. atual. e ampl. - São Paulo: Revista dos Tribunais, 2017.

Data da submissão: 30/04/2020

Data da primeira avaliação: 16/06/2020 Data da segunda avaliação: 10/11/2020

Data da aprovação: 10/11/2020 